This is an authors' accepted manuscript for 'Psychoanalysis, Culture \& Society', copyright Palgrave Macmillan.

Black, J., Lake, R.J. and Fletcher, T. (2021) An Unnerving Otherness: English Nationalism and Rusedski's Smile. Psychoanalysis, Culture \& Society.

https://link.springer.com/article/10.1057\%2Fs41282-021-00235-3

\title{
An Unnerving Otherness: English Nationalism and Rusedski's Smile
}

Dr. Jack Black, Academy of Sport and Physical Activity, Faculty of Health and Wellbeing, Sheffield Hallam University, Collegiate Hall, Collegiate Crescent, Sheffield, S10 2BP

Dr. Robert J. Lake, Department of Sport Science, Douglas College, New Westminster, British Columbia, Canada

Dr. Thomas Fletcher, School of Events, Tourism and Hospitality Management, Leeds Beckett University, Leeds, UK 


\title{
An Unnerving Otherness: English Nationalism and Rusedski’s Smile
}

\section{Jack Black, PhD}

Academy of Sport and Physical Activity, Sheffield Hallam University, Sheffield, UK

\section{Robert J. Lake, PhD}

Department of Sport Science, Douglas College, New Westminster, British Columbia, Canada

\section{Thomas Fletcher, PhD}

School of Events, Tourism and Hospitality Managament, Leeds Beckett University, Leeds, UK

\begin{abstract}
In view of scholarly work that has explored the socio-psycho significance of national performativity, the body and the "other," this article critically analyses newspaper representations of the Canadian-born British tennis player Greg Rusedski. Drawing on Lacanian interpretations of the body, it illustrates how Rusedski's media framing centered on a particular feature of his body—his "smile." In doing so, we detail how Rusedski's "post-imperial" Otherness—conceived as a form of "extimacy" (extimité) — complicated any clear delineation between "us" and "them," positing instead a dialectical understanding of the splits, voids and contradictions that underscore the national "us."
\end{abstract}




\section{Keywords}

extimate; Lacan; Englishness; fragmented body; the other

In this article, we examine how debates on English nationalism/national identity were played out in newspaper coverage of the Canadian-born British tennis player Greg Rusedski (now retired). Specifically, we explore how newspaper representations of Rusedski align with scholarly work on national performativity, the body and the "other", drawing particular attention to how Rusedski's media framing centered on a particular feature of his body-his "smile". It is through this "smile" that wider anxieties, confusions and contradictions regarding English nationalism/national identity were exposed.

In order to elucidate on the significance of Rusedski's "smile," we turn to Lacanian analyses of the body (Aoki, 1996; Winnubst, 2004; Žižek, 2008) and, in particular, Lacan's $(2000,2010)$ notion of the "fragmented body." Central to this analysis will be the concern that media representations of the "other's" body prove effective in helping to explicate a number of English "confusions," anxieties and political inhibitions regarding its national identity, culture and location within a devolved UK state. Attention will first be given to exploring these confusions in light of debates on Englishness and English nationalism/national identity. This will be followed by a discussion of Lacan's Imaginary, Symbolic and Real orders, with particular attention given to the body and its role in examining the nation and the "other." Subsequently, the findings and conclusion will consider the relation between Rusedski's "smile" and underlying tensions in English nationalism/national identity. 


\section{English nationalism/national identity: An inconsistent and confused identity}

Studies on English nationalism and national identity have frequently highlighted the effects of English-British conflations in political and popular discourse. These conflations are grounded by the fact that the "national sovereignty" of England is marked by its location within a multi-national state: the UK. Indeed, it is due to this shared socio-political status that speaking specifically about an "English" national history, identity and culture requires one to refer to what Baucom (1999) terms a "history of $[\ldots]$ cultivated confusion" (p. 1). Though England maintains a certain hegemony in UK politics, its culture, identity and ability to organise a distinctly separate "English" political movement (similar to that achieved by the Scottish National Party) is often inhibited or even outright prevented (Aughey, 2010).

Located amidst these debates and tensions has been an ongoing focus on delineating what Englishness is and, more importantly, who belongs to such a national description. These tensions can be brought to bear in Malcolm's (2013) use of Edmunds and Turner's (2001) "malign" and "benign" models of Englishness, in which he notes:

Malign Englishness is described as closed (e.g. resentful of other nationalisms), insular (e.g. threatened by European identities and multiculturalism), earnest (e.g. seeing national identity as 'in the blood' and rejecting the idea that traditions are invented), masculine (e.g. aggressive) and reactive (e.g. defensive of traditional and nostalgic notions of Englishness). Benign Englishness is open (e.g. tolerant of other nationalisms), cosmopolitan (e.g. enjoying the co-existence of different 
cultures and welcoming of multiculturalism), ironic (e.g. aware of the contingent character of national identities), feminine (e.g. pacifist), and creative (e.g. actively seeking to build an identity of openness, liberalism and tolerance). (Malcolm, 2013, p. 123)

It is our contention, however, that the division between a "malign" and "benign" Englishness points more to an inherent inconsistency within Englishness itself. Certainly, the effort here is not to categorise English identity as either/or (malign/benign), but, instead to view such opposing trends as reflective of a split, tension or antagonism in the conception of Englishness. Moreover, this allows us to draw connections with what the philosopher Slavoj Žižek identifies in Hegel's “true” ideal State (Žižek, 2016). In contrast to Hegel's dialectical synthesis, Žižek asks:

Do we finally get the true notion of State with the concept of modern constitutional monarchy described by Hegel in his philosophy of right? No: the ultimate result is that the "contradiction" (antagonism) is internal to the notion of State as such, so that a "true" state is no longer a state. (pp. 100101 , italics added)

This Hegelian assertion underscores the inherent antagonisms which have shaped, and continue to shape, today's Western liberal democracies (such as the UK). In so doing, Žižek (2016) draws attention to the systematic failure embedded within any attempt to idealise a "harmonious social body"; emphasizing, instead, the inherent antagonism(s) that constitute such forms (i.e. "nation/nation-states"), as well as the 
fantasy formations that obscure these antagonisms. As Finlayson (1998) argues, "the process of establishing a definitive conception of the nation is never completed, just as the process of establishing a permanent, fixed, subjectivity is ever incomplete" (p. 158). Indeed, it is such "incompleteness" that continues to confound English nationalism/national identity.

What these confusions, inconsistences, fears and anxieties allude to is: "how nationalistic identity is based on [...] [a] gap or negativity that lies beneath the illusion of consistency and harmonious synthesis" (Wood, 2012, p. 37). Here, national "Fantasy functions so as to camouflage the Real antagonism that ruptures any (allegedly) organic, social unification" (p. 37). These ruptures are not just inherent to the nation, but, as reinforced by Finlayson (1998), underscore Lacanian accounts of the subject and, specifically, the importance of national fantasies that provide a sense of imaginary wholeness for the subject. In what follows, further consideration will be given to examining this process with regard to the body.

Fragmentation, inconsistency and the excessive remainder: A Lacanian approach to the body

Lacan's $(2000,2010)$ reference to the body is one that remains tied to his conceptions of the self-divided subject. In order to expound upon the effects of this division, we can consider the relation between Lacan's Imaginary and Symbolic orders.

With the Imaginary, "Lacan explains that the first step in subject formation is the acquiring of an imaginary body" (Inahara, 2009, p. 50). This is explained in his "mirror stage," which denotes how the subject is formed in relation to an 
imaginary wholeness that they conceive in/through the mirror (Lacan, 2010). Located in infancy, this sense of "imaginary wholeness" is what "Lacan frames [as] the primary psychic sense of the body - and, subsequently, of the self - as it is seen" (Winnubst, 2004, p. 31). Yet, importantly, the subject that is formed in accordance with the image they see in the mirror is an "imaginary object," marked by a perception of prior fragmentation. As a result, the image is always threatened by the possibility of disunity. We do not necessarily have to see this stage as encompassing a literal "mirror," but, rather, use it as an example of how "the shadow and the mirror image are the obvious analogues of the body, its immaterial doubles" (Dolar, 1991, pp. 11-12). In the same way that "The shadow and the mirror image survive the body due to their immateriality — so it is that reflections constitute our essential selves" (p. 12).

More importantly, it is following this "immaterial double" that the bodyand specifically the subject — undergo a "symbolic castration" (p. $11 \& 12$ ). This occurs through the Symbolic order as it serves to mediate the subject's languagedevelopment. That is, the interpellation of the subject in the Symbolic order - that of reality, language and the customs, habits and values which define a culture - is a process that is forever marked by "a nostalgic fantasy image of a lost oneness" (Wood, 2012, p. 20). Wood is not suggesting that there was some pre-symbolic "body" which, for the subject, was "lost" before symbolic castration; instead, the subject is - through the process of "symbolic castration"- - forever beset by a lost sense of bodily wholeness that remains dependent on a Symbolic order that is itself never fixed nor stable, but marked by the inconsistency of the signifier (Myers, 2003). This sense of fragmentation can be seen in Black's (2011) account of how the "internalized conceptualizations of faces results from the fundamental 
irreconcilability of the living face with [a] fixed, stable identity and representation" (p. 16, italics added).

It is with regard to such irreconcilability - that which always seems to escape signification - that a certain "remainder" serves to constitute the subject. Certainly, as Žižek (1996) notes, "this remainder does not point towards the irreducible self-presence of 'our own' body, accessible to us in an immediate selfexperience" but, instead, reveals how "our bodily self-experience is always-already 'virtual', i.e., sustained by series of imaginary and symbolic identifications" (p. 525). Indeed, what Lacan's conception of the body reveals is how we can never "isolate the materiality of the body from the messy tangles of inscription and meaning that arise from internal as well as external forces” (Lemma, 2017, p. 43). Instead, the body is always marked by the Real; that which is "foreclosed from language, symbolisation and meaning” (p. 43).

The Real occupies a central role in Lacan's understanding of both the Imaginary and Symbolic orders, and is given further explication by Žižek (2008):

We have the Real as the starting point, the basis, the foundation of the process of symbolization $[\ldots]$ that is, the Real which in a sense precedes the symbolic order and is subsequently structured by it when it gets caught in its network: this is the great Lacanian motif of symbolization as a process which mortifies, drains off, empties, carves the fullness of the Real of the living body. But the Real is at the same time the product, remainder, leftover, scraps of this process of symbolization, the remnants, the excess which escapes symbolization and is as such produced by the symbolization itself. 
In Hegelian terms, the Real is simultaneously presupposed and posed by the symbolic. (p. 191)

This suggests that rather than being an effect of language, the body provides a site for the limits in language; with the capacity to ever achieve a complete meaning always failing.

It is from this perspective that we can begin to conceive how the body occupies a certain locus which both upholds and disrupts our symbolic constructions (Aoki, 1996). Importantly, Lacan's $(2000,2016)$ work would later be extended in his seminar on anxiety. What we wish to draw attention to in this paper, however, is the partial and fragmentary significance of the body for Lacan, and, specifically, its relation to extimacy and otherness in the context of nationalism (Nasio, 1998). To this end, we emphasise the Lacanian contention that "the subject exists as the effect of our particular failure to reestablish the fantasy of bodily coherence" (McMillan, 2015, p. 553). This failure can be identified in the "split" that forever marks the subject's entry into language; that is, in "the void created by splitting the body from itself in what Lacan called symbolic castration" (p. 553). Again, this does not position "the body" as a force beyond the Symbolic, but rather points to its constitutive failure within the Symbolic order.

For example, Aoki's (1996) Lacanian approach to female body building and sexuality reveals how norms concerning "the body" - in this case, a heterosexist performativity — are both maintained and marked by a sense of radical "Otherness" (the female bodybuilder) that reveals the inherent contradictions within the apparent integrity of the Symbolic order. Certainly, this is not to raise the "other" to some sublime position beyond human contemplation, but rather draws attention to how 
such practices disrupt the fantasy constructions which underscore the Symbolic order. Conceived as a failure, a void and disruption, it is this "otherness" which inherently plagues examples of nationalism. In what follows, we turn to our understanding of the "other" and how, through a process of "Othering," the nation seeks to achieve a sense of wholeness.

\section{Nationalism and the body: an extimate "other"}

As the previous section has detailed, no Imaginary or Symbolic construction is ever "complete" and "stable," but is rather marked by a sense of contradiction and/or antagonism (i.e., the Real); a malignant negativity through which the subject—and the body-is marked by an inherent "Otherness." Furthermore, if we extrapolate these ideas in accordance with scholarly work on nationalism and the body, then we can begin to see how such analyses go beyond simply distinguishing between an "us" and a "them" - a distinction which sustains any group via a demarcated "outside" - and instead turn inwards: to those differences and forms of "Otherness" which are so internally contradictory for the subject and which prove so antagonistic for a coherently defined nationalism/national identity.

Indeed, "The notion that 'they' can be equal collaborators in remaking our common culture rings alarm bells in all who share this anxiety" (Taylor, 2012, p. 420); an anxiety which is all too easily reflected in fears regarding one's national culture (and its decline) and which, with regards to the body, become arbitrarily defined through the body's demarcation; for instance, the "other's" hair, phenotypical skin colour or accent (Seshadri-Crooks, 2000). In fact, if we remember that the body is marked by a sense of "lack"—a lack which is subsequently obscured 
through the Imaginary's fantasmatic wholeness-we can begin to see how the positing of a "they" or "them" works to ensure that, for the national subject, what is "lost" can in some way be recalled through an expulsion of the "other." Whether the "other" is stealing what we "have" (therefore resulting in "lack") or reminding us of our "lack" (through their excessive enjoyment), we are, nonetheless, embroiled in a process of self-consciousness that is marked by an inherent limit forged in accordance with the "other."

Understandings of the other and the "limits" that structure and constitute our relations with the other form an integral part of Emmanuel Levinas's (1998) account of the face. Black (2011) highlights how, for Levinas,

the face represents the paradox of imagining that the Other experiences an inner life like one's own while simultaneously only being able to interact with the Other as a sealed exteriority, which implacably hides the truth of this posited interior life from us. The full truth of the Other is ultimately lost behind the face or between the features and expressions it presents to us. (p. 20)

Underlying Levinas's interpretation is the extent to which "the face as a material component of the body [...] is never fully fixed, grasped or possessed by the viewer of that face" (Black, 2011, p. 21). It is in the process of encountering the other's face that the "limits" which underscore one's affinity with the other can be found (Ruti, 2015). Thus, we are obliged "to protect the other regardless of how this other appears to us, regardless of whether or not we experience the other's face as benevolent" (Ruti, 2015, p. 194; see also Levinas, 1998). As a result, "The full truth 
of the Other is ultimately lost behind the face or between the features and expressions it presents to us" (Black, 2011, p. 20).

Criticisms of Levinas's face can be found in work that has extended his encounters with the other in accordance with the ethical and racial importance it presents (Ruti, 2015; Zalloua, 2020). Indeed, while the significance of Rusedski's face - and, specifically, his smile - proved integral to his media framing, we consider how criticisms of Levinas's face can be extended via an account of the Lacanian body. For example, in the previous section, attention was given to tracing how Lacan's (2000) “fragmented body" undergirds any imaginary or symbolic association that may be attributed to the body. Yet, despite attempts to afford some sense of unitary wholeness, the body maintains a Real significance-a limit that forever disturbs the body's gentrification. When considered in light of Levinas's (1998) face, we can begin to see how efforts to approach the other remain dependent upon the very symbolic and imaginary identifications that one attributes to the other and, thus, it is in accounts of the body and the other (the other's body) that a certain uncontrollable excess, which refuses any symbolic or imaginary location, can be found. In other words, any attempt to "manage" or console oneself with this excessive otherness serves only to "distrac[t] us from the fact that, underneath the face, the other is radically unknowable" (Ruti, 2015, p. 194).

We do not seek to privilege this sense of "unknowingness," but rather draw attention to the constitutive role played by it in theoretically aligning accounts of the other, the body and, ultimately, the nation. Here, we draw attention to the specific limitations that constitute any national construction, including that which refers explicitly to those others deemed "outside" the nation, but who, nonetheless, remain integral to such constructions. At the heart of this approach, therefore, is the 
assertion that the inherent impasses and internal contradictions which constitute the nation are themselves played out in framings of the other's body.

In what follows, we highlight how this can be brought to bear via Lacan's notion of the "extimate" (extimitê). According to Zupančič (2019), "extimate" refers to

an excluded interiority or an included exteriority; an intimate exteriority or external/foreign intimacy, transversal to the divide between Outside and Inside; a coincidence of something most intimate, intrinsic to me, with something most external and foreign; something that belongs to me, yet at the same time strikes me as utterly foreign, disgusting even. (p. 90)

In short, the extimate can be used to highlight how "The unfathomability of the other resides within us" (Lemma, 2017, p. 22). It is this dialectic procedure which locates difference not just between those groups perceived to constitute and not-constitute the nation, but within the nation itself. It is a distinct sense of "us" which comprises the nation's difference through its own internal limitation (Malcolm, 2013).

Set against the UK's imperial—and, therefore, multinational/multiculturalpast, this approach allows us to explore how media framings of the "other" can be reconceived as incorporating those differences that prove inherent to the nation itself. In particular, we observe how media discourses of the "other"-and, specifically, the "other's" body_prove amenable to identifying those inherent inconsistencies that underscore the nation. In what follows, we locate the inconsistencies, contradictions and antagonisms in English nationalism/national 
identity asreflected in media discourses on the Canadian-born British tennis player Greg Rusedski. In doing so, we highlight how Rusedski’s media representation disclosed, and even emphasised, English anxieties regarding its national identity, reflected in an English/British conflation and fixation with the "other"; or, in the case of Rusedski, a particular aspect of his body which served to constitute his "Otherness": his "smile".

\section{Methodology and method: Greg Rusedski and English press analysis}

Born in Montreal, Quebec (Canada) in 1973, Rusedski chose to play for "Britain" in May 1995, with his eligibility secured through his English mother. For many athletes who currently represent and have represented "Britain" the United Kingdom and Northern Ireland (Team GB) or any of its constituent "home nations," Rusedski's decision to do so reflected a long history of former imperial subjects and, later, Commonwealth citizens who have chosen to compete for Britain instead of their country of birth.

In many ways, Rusedski's decision remained marked by his apparent "foreignness"- - he spoke with a Canadian accent, a fact that was widely reported within the press (Anthony, 1997; Dickson, 1997b; Powell, 1997)—and a career rivalry with the English-born Tim Henman. In fact, these tensions are further complicated when we consider that, in the case of tennis, any player born in England, Northern Ireland, Scotland or Wales competes for "Britain." Accordingly, though newspaper framings of Rusedski sought to emphasise his "Canadianness" in contrast to media depictions which often emphasised Henman's Englishness (though noticeably rarely his "Britishness"), we can begin to see how such framing 
proved reflective of wider English-British tensions, seen more recently in the case of Scottish-born British tennis player Andy Murray (Harris, 2019).

The methodological approach adopted in this paper is broadly congruent with previous British sport-media narrative analyses across a range of sports (see Black, 2016; Bignell, 1997; Malcolm, 2012). Newspaper articles from among the leading English/British (London-based) broadsheets featuring commentary on Greg Rusedski throughout his professional career, were comprehensively examined namely The Times/Sunday Times, The Guardian/Observer, The Telegraph/Sunday Telegraph, The Independent/Independent on Sunday, The Financial Times and the Daily Mail. Since tennis is a broadly middle-class sport, it was the broadsheets that seemed, perhaps naturally, to take more of an interest in it and critical discussions of Rusedski's identity. These articles were obtained digitally through digital repositories such as InfoTrac and Newsstand International. All articles featuring Rusedski's name were initially examined (over 1,000), but of these approximately 350 included meaningful data related to the framing of Rusedski's national identity or discussions of his body/smile, and so were shortlisted for detailed analysis. Open coding was used to group relevant findings from the text of these sources and repeated re-reading and analysis of the data allowed for the emergence of several themes, outlined below. Of most interest were detailed and in-depth feature articles and more critical pieces discussing aspects of Rusedski's identity, alongside his body and personal appearance, or specifically his smile.

\section{Fixing the face}


Before examining the press's obsession with Rusedski's "smile", it is appropriate to discuss that part of the body where the smile can be found: the face. As previously noted, for Black (2011), the face occupies a unique role in the anatomical structure of the human body, serving as both a tool for communication as well as affording a perceptual significance. Here we often refer to "the face" as a way of signaling a person of significance as well as drawing attention to a particular "someone" who, through their "facial" recognisability, is used to represent a particular group, as denoted via the often-cited phrase "the face of...". In fact, over the course of their careers, both Henman and Rusedski were depicted as competing to be the "face" of British tennis (Stafford, 1995), with Henman's perceived marketability and "middle England" charm ensuring such a position (Broadbent, 2003). In this sense, it was Henman's "face" that was fixed with a particular set of meanings and an embodied significance that tied him specifically to British tennis and British culture (see also Magli, 1989).

Moreover, though we often see a number of discernible attributes applied to the face's various features - for example, there is perhaps no better illustration of the fixating of the face to certain restrictive categories than in the case of racism, where facial features (the nose, the lips) become symbolically employed to support racist ideologies (Black, 2011) - it is in "fixing" these features that relations with the "other" become marked by some form of (hidden) internal "essence" which serves to constitute the "others" Otherness.

In the case of Rusedski, it was a fixation with his "smile" that provided the most troubling significance. After a defeat to Henman at the Australian Open that included Rusedski's expletive-filled tirade aimed at the umpire, Lawton (2002) noted how Rusedski's loss "forced the revelation that behind the gawky smile of his 
opponent lurked just another overgrown tennis brat" (p. 20). Indeed, it was only when the press went "behind" the "smile" that Rusedski's true "essence" — in this case, his very "un-English" lack of emotional control— was inferred.

Elsewhere, Rusedski was explicitly referred to as the "smiling boy" (Riley, 1998, p. 19) and “Grinning Greg” (Dickson, 1997a, p. 80, 1997c, p. 56). Interestingly, even in contexts which appear antithetical, for example, stories focusing on Rusedski's technical and playing abilities, there remained a fixation on his "smile": “A 6ft 4in Canadian with a wide grin and a rocket serve" (Atkin, 1998, p. 3; see also Roberts, 2004, p. 5). Writing before Rusedski's appearance at the 2001 Wimbledon Championships, Holden (2001) noted:

Greg Rusedski will carry three vital props onto court as he chases the Wimbledon title [...] There is the little tool that straightens the strings of his tennis racket $[\ldots]$ There is the white towel with which he wipes his forehead after every other point $[\ldots]$ Most of all, though, there is the smile. Always the smile. It is the smile which charms the crowds, the smile which disarms fragile opponents, the smile which sustains his renewed self-belief, the smile which is a glowing symbol of his more relaxed approach to tournament tennis. (p. 115)

Certainly, despite Holden's rather positive appraisal of Rusedski, and his preparations for the tournament, it was clear that it was his "smile" which bore an important significance, not just in the press's labelling of Rusedski, but also in the extent to which the framing of his "smile" steered towards his beguiling personal differences. 
In amongst references to Rusedski’s “cheesy-grinning” (Edworthy, 1999, p. S6) and what seemed to be, for the press at least, his almost deliberate use of his “trademark grin" to garner commercial benefit (Barrett, 2004, p. 14), were those examples that served to draw upon Rusedski's "smile" as a key feature in distinguishing his "Otherness." Returning to our Lacanian interpretation of the body, we can observe how the "smile" can both signal but also occupy that undigestible "remainder" which posits the body. Indeed, Lacan demonstrates this remainder by referring to the Cheshire Cat from Lewis Carroll's well-known novelAlice's Adventures in Wonderland. In one notable scene in which the cat speaks to Alice, his body slowly disappears with only his smile remaining. Here, “The persistent grin of Alice's Cheshire cat, the 'grin without a cat', shows that even when the body dissolves, something indestructible is left as a remainder" (Gherovici and Steinkoler, 2016, p. 17). It is "This grinning grimace [which] reveals the Lacanian Real," something which is "beyond speech and understanding" but which, nonetheless, "uncannily insists" (p. 17). In particular, such insistence arises when "the link between the body and the signifier [...] includes a point that is not reducible to either one of them" (Zupančič, 2008, p. 52). Instead, "in order for this link to be established, something needs to be subtracted" (p. 52). For Lacan (2010), this subtraction often centres around a certain "partial object" (objet petit a), which, through its partiality, becomes subtracted from the body and, as seen in the example of the Cheshire Cat, serves to constitute the person to whom it belongs. In other words, as their remainder, the partial object works as that "part" of the body which, on its own, encompasses the perception of the individual (i.e. the "smile").

It is through this partial object that the incompleteness of the subject—an incompleteness which bears witness to the "other's" (and the subject's) Otherness- 
can be averred. Yet, what is important is that such "incompleteness" posits its own limitations, from which perceptions of the "other's" body are presented via "a mysterious and partially defined them" (Howie, 2012, p. 93). Consequently, in the press coverage, Rusedski remained a mystery who achieved his resonance through the subtraction and partiality of his "smile." In what follows, we consider how it was through this partial object - his "smile"- that Rusedski's Otherness was articulated and defined.

\section{"There was something about Rusedski": Middle England, "Otherness" and authenticity}

As previously highlighted, forms of cultural difference are often tied to or demonstrated by the "other's" body, including their accent, their appearance and, specifically, their facial features. In the case of Rusedski, it was his "smile" that served a particular point of contention for including him within any perception of what could constitute Englishness. These contentions were clearly displayed in examples such as Hayward (1997), where it was made clear that for "middle England”, Rusedski was "a turn-off” (p. 25). For a section of the English populace that "still thinks of tennis alongside warm beer and village cricket $[\ldots] \mathrm{He}$ [Rusedski] was little more than a headband and a McSmile, which he seemed to maintain through all manner of on-court fiascos" (p. 24). Hayward's comments draw upon a number of significances pertaining to the provincialism of England as a form of ontological security, as well as the conflation of Rusedski's Canadian birth with its North American neighbors, the United States. 
First, the reference to "middle England" was often reprised across English newspaper reports (Barnes, 2004; Powell, 2004), with the term's wider significance being used as a metonym for a middle-class, right-wing, politically conservative form of Englishness (O'Sullivan, 1998). Repeatedly, the reference was used to position Rusedski in contrast to Henman's Englishness and his apparent favour amongst those "Englanders" who held such a socio-political position (Lawton, 2003). Second, Hayward's (1997) reference to Rusedski's “McSmile” presented a play on the US fast food franchise McDonald's. While the reference to McDonald's can be read as signifying the often-cited criticism that Rusedski had simply chosen Britain for the commercial incentives that this would provide (an incentive which reportedly undermined his apparent desire to play for Britain), it nonetheless served to frame Rusedski with a distinctly foreign and, in the eyes of the English (press), decidedly North-American sporting character. This was also seen in references to Rusedski’s “film star teeth” (Barnes, 1995, p. 46) during his first Wimbledon Championships, which positioned him as closer to Hollywood-both in geographical location and cultural representation - than the tennis courts of SW19.

Again, in denouncing Rusedski's foreignness, newspaper coverage frequently drew links between his "smile" and certain Canadian cultural and geographical attributes. For example, Edmondson (2005) noted how, "It takes little trouble to imagine the big smile among the giant redwood, the fir and the mighty Scots pine, leaping from tree to tree as they float down the mighty rivers of British Columbia" (p. 77). Equally, others, such as The Independent (1995), highlighted Rusedski’s marketability: “A smile as wide as Saskatchewan [which] has been Rusedski's biggest selling point" (p. 4). The extent of Rusedski's "smile" was similarly used to emphasise the distance between Canada (i.e., him) and the UK 
(i.e., us). According to Roberts (1995), Rusedski had "a smile as wide as the Atlantic" (p. 28); "usually stretch[ing] from Montreal to London" (Roberts, 2001, p. 20). What remains important in these examples, is the extent to which Rusedski's "smile" came to epitomise his "Otherness".

This "Otherness" was demonstrative of two fundamental contentions in the framing of Rusedski. First, his lack of authenticity, as noted in Baker's (1997) comments regarding Rusedski’s "British Sportsperson of the Year" award:

Rusedski was the people's choice. His speech of acceptance was charming and modest, his smile as wide and bright as the White Cliffs of Dover. Who would quibble when a nice guy finishes first? Some would. Those who claim that Rusedski's niceness is superficial, that he is saccharine and shallow. (p. 40)

The superficiality and, therefore, the perceived inauthenticity of Rusedski's nationality, remained anchored to his charming "smile"; a smile that was perceived to reflect a level of subversivity which eerily revealed that his "nice guy" image was a sham. This invasive questioning of Rusedski and his motives was echoed in accounts of his "grinning wholesomeness", which ensured that his "smiling and charming [... led] to more success" (O’Hagan, 1995, p. 23) by means of a "flashing smile" that, for Philip (1998), was just "as manufactured as his tennis" (p. S5). What becomes apparent in each of these examples is the extent to which his "smile" provided the symbolic lynchpin from which his "inauthenticity" could be framed.

Second, there was a deliberate sense in which such a "wide and bright" smile (Baker, 1997, p. 40) could reveal an unnerving “oafishness.” For example, Barnes 
(1996) noted that "There is a kind of oafish likeability about him, despite the grin" (p. 44). In fact, Rusedski's “oafish" demeanor was given an explicit comparison in Cooke's (2001) framing of his physique (and his "smile") with the Monster from Mary Shelley's Frankenstein:

It strikes me how weirdly deliberate his physique is - as though he was put together in a laboratory by a team of tennis-mad scientists. His arms are long and dangling and visibly ache for a racket to raise aloft, his hands are as big as dinner plates and his shoulders are a couple of rounded cliffs you can see for miles around. Even his smile [...] is as wide as the Tyne bridge. (p. 2)

Equally, for Barnes (2007), 'There was something about Rusedski'; a "something” that became reflected in "that still disconcerting grin $[\ldots]$ [and] the wariness behind it" (p. 49, italics added).

Though not always referring explicitly to Rusedski's "smile," these examples still managed to draw upon his body to articulate wider concerns - the over-commercialisation of sport; Rusedski's "authenticity" and "Otherness" alongside anxieties and open hostility towards his eligibility to play for Britain. Take this example from Powell (2004):

Even when he lost in the U.S. Open - which we came sickeningly close to celebrating as a British triumph - he lost to Aussie he-man Pat Rafter with a whimper. Not to mention a lopsided grin. The Rusedski smile, heaven help us, had become part of our sporting landscape. Are we really that desperate for success? (p. 93) 
Although referring to Rusedski's defeat, Powell's (2004) final rhetorical question offers a unique insight into the anxieties that underscored Rusedski's success. Indeed, it would seem that, from Powell's assessment, the British public's decision to include/embrace Rusedski says less about his "authenticity" as a "British" person and more about their desperation to find a competent tennis player who could compete for Britain.

To this end, we can begin to reveal how, as a partial object, Rusedski's "smile" presented a form of "extimacy" for the English press. That is, what Rusedski's inclusion presented was a direct engagement with a perceived external threat that spoke more to the "excluded interiority" that underscores as well as frames that piece of the Real, and which constitutes one's subjectivity. Specifically, it is through this extimate remainder that what is intrinsic provides an uncanny disturbance for the subject—what the extimate reveals is the subject's "Otherness"; an "Otherness" that, in the case of the nation, becomes directed towards some externally perceived "other".

Accordingly, while “people's engagements with 'others' are frequently marked by inconsistencies, shifting needs and desires and, above all, attempts to ensure a degree of control (however limited) of their everyday environments of action" (Skey, 2013, p. 245), in the above examples a similar "degree of control" was conceived in relation to those reports that sought to fix Rusedski's "Otherness" through his unnerving and unyielding "smile." What these attempts reveal, however, is how such othering proved conducive to an "inside/outside" dialectic that routinely sought to make sense of its own extimacy. 
This extimacy can be observed in the attributed nickname with which journalists from The Times (Barnes, 2004; Jones, 1995) provided Rusedski. For Barnes and Jones, Rusedski's "smile" earned him the nickname "The Joker"reference to the popular comic book villain, Rusedski's comparison with whom was guided by the fact thatRusedski was "constantly wear[ing] a broad grin" (Jones, 1995). In the various cultural renditions which draw from the character (the character has been included in comic books, computer games and films), The Joker remains an unsettling force of maniacal anarchy, constantly terrorising the fictional Gotham City. In fact, what remains consistent across The Joker's fictional representations is how he serves as a force that is both of, but which also emerges from within, the city itself. In other words, The Joker is that "external interiority" which encompasses Gotham's inherent antagonisms, while also serving as the inherent alien presence which Gotham seeks to repel.

There is, of course, a connection between the unnerving smile of The Joker and English newspaper depictions of Rusedski. In short, what Rusedski's "smile" seemed to encapsulate was that unnerving "Otherness" which encompasses the confusions and inconsistencies that underscore English nationalism/national identity. In the following conclusion, we seek to support this argument by providing a final précis on Rusedski, the "smile" and its relation to English nationalism/national identity.

\section{Further Discussion}

An important and ongoing discussion in debates on Englishness, its culture and its identity is the relative attention and/or significance that it affords to its imperial past. 
For Easthope (1999), this complication is rendered explicit by the fact that "England can still neither face nor forget the Empire and loss of Empire” (p. 31). Indeed, to remove or even ignore this past is to risk emptying England (and the rest of the UK) of an important national imaginary; an imaginary that continues to gain much of its traction through its various appropriations and manifestations. In the case of sport, this manifestation remains integral to media coverage on English/British sport, shedding further light on the complications that arise in legally drawing upon foreign-born athletes to play and compete for England/Britain.

If we returning once again to our Lacanian framework, for Bentley (2007) these complications reveal how it is the Real which remains integral to any symbolic construction of "England." Here, "Colonialism in its 'Real" form is impossible to imagine if any imaginative and symbolic sense of Englishness is to be maintained" ( p. 487). What this (Real) imperial past serves to aver, however, is a more disturbing and, perhaps, unnerving realisation: there is no Englishness. This is not to suggest that evocations of Englishness, for which there are plenty, are mere allusions that remain subjected to the actions and performances of those deluded by a national attachment and sense of feeling that being English provides them. Rather, it is suggested that it is through the "other," and in this case Greg Rusedski's "postimperial" Otherness (specifically, his "smile"), that the press's imaginings of Englishness came "face-to-face with the Nothingness at its centre" ( p. 487). While one might assume that the fixation of the press on a particular bodily feature belonging to a Black athlete - such as their nose, lips, hair or general physiquewould quite rightly be condemned as a form of racialization, Rusedski's framing proved an almost open form of national xenophobia: one heralded by his apparently un-English smile. As a "extimate" object, however, Rusedski's "smile" presented a 
form of objectification that both masked and obscured the contradictions at the heart of Englishness, especially, we conclude, those pertaining to whiteness and theories of white privilege.

Unlike in the vast majority of other studies on nation, sport, race, the body and otherness where the focus tends to be orientated towards visible or phenotypical difference(s) - i.e., Blackness and/or Asianness - our focus on White otherness offers both originality and an opportunity to reflect on otherness in the context of white ethnicities and whiteness. Historically, whiteness has been viewed as normal, with many academics alluding to the invisibility of White ethnicities. Indeed, studies of whiteness have asserted that White people do not see themselves as "raced," yet enjoy privileges as a result of their whiteness (McIntosh, 1988). These ideas have been supplemented by the defense of White privilege through colourblindness, learned ignorance, meritocracies and broader ideals of level playing fields and notions of racism's demise emerging in post-race discourses (Gilroy, 1998; Leonardo, 2009). Leonardo (2009) suggests that whiteness gains a significant amount of its power by "Othering" the very idea of ethnicity.

This begs the question of how privilege is variously experienced by those racialized as White, and, more importantly, of the problems in adopting a theory grounded in "privilege". For example, we do not assert that to be White is to suggest that all privilege is experienced in the same way, or to the same extent. Within the White racialized hierarchy there are a number of strata with varying degrees of acceptability or, as Long and Hylton (2002) suggest, different "shades of White." In fact, among those who appear phenotypically White-including Irish; Jewish; Gypsy/Travellers; and new migrant communities such as Eastern Europeansexamples of marginalization continue to occur. Indeed, much of the backlash against 
the global Black Lives Matter movement stems from the realization that many of these groups are discriminated against in other ways (e.g., by socioeconomic class, gender and so on) and therefore do not necessarily "feel" privileged (Evans et al., 2020). Rusedski is a prime example of an athlete, racialized as White, who experienced many of the privileges of being White, though similarly was never fully accepted as English.

On this ground, we conceive of Rusedski's framing as dislodging any assertion that race/ethnicity can be "privileged," if only for the fact that such a logic would, on the one hand, confirm racist sensibilities, grounded in the concern that race/ethnicity can be measured along a scale of deserving and undeserving privilege; and, on the other, (?can) effectively redouble forms of racism which seek to identify and delineate those deemed to not have "earned" their privilege.

To this, we conclude that the above examples, drawn from the press's framing of Rusedski's "otherness," help to highlight two important distinctions. First, "rather than simply describing what whiteness is," we echo McDonald (2009) by asserting that "it is more useful to explain what whiteness does" (p. 9). Indeed, while Rusedski's English acceptance remained "unaccepted”- a point drawn from the frequent references to his smile and its inherent otherness - these framings worked to reveal the "unearned privileges" and "negative advantages" that his decision to compete for England sought to aver (Zalloua, 2020, p. 30). Consequently, in accordance with the concern that there is no Englishness, it was in its very framing of Rusedski that the English press came face-to-face with the utter banality of its "privileging" system, itself grounded in systematic forms of obscured racial inequality. 
Second, it is from this basis that Rusedski's framing presented an opening for "sustained interpretive scrutiny" (Z p. 38), providing an opportunity to elicit and identify the inherent contradictions - what this article has conceived as examples of extimacy — that underscore representations of race, ethnicity and the nation. Here, Rusedski's framing brought to bear a constitutive otherness that did not rest "outside" of English nationalism, but rather formed an integral, and indeed contradictory, part of its national construction. We would go as far as to suggest that this contradiction was itself dependent upon a certain neurotic resentment within the English press (Fink, 2000); a resentment brough to light in what were, on the face of it, rather trivial (yet significant) forms of difference (his smile, accent and teeth). We posit that it is in recognizing this ontological inconsistency in Rusedski's framing that a far more definitive rupture within English nationalism (including its "racial status quo") could be observed (Zallous, 2020, p. 31).

Therefore, what the English press's framing of Rusedski revealed was the unnerving realisation "that every empirical Englishman contains something "nonEnglish"” (Žižek, 2002, p. 110). That is, "Englishness [...] [is] an 'internal limit', an unattainable point which prevents empirical Englishmen from achieving full identity-with-themselves" (p. 110). Though achieving some (minimal) sense of "full identity" proves constitutive of any subject, it was, nonetheless, in the framing of Rusedski that this "internal limit" could be found. It is here that Rusedski's framing complicated any clear delineation between an "us" and a "them," towards a dialectical understanding of the splits, voids and contradictions that constitute the national "us." Instead of analysing and critiquing the mere "performativity" of the body, this article highlights that it is through the body that the nation's inherent 
limitations are enacted via forms of obfuscation that work to both separate and delineate the "other."

Jack Black is a Senior Lecturer at Sheffield Hallam University. His research examines the interlinkages between culture and media studies, with particular attention given to cultural representation and ideology. His recent Race, Racism and Political Correctness in Comedy - A Psychoanalytic Exploration (Routledge, 2021) critically considers the importance of comedy in challenging and redefining our relations to race and racism.

\section{Endnotes}

${ }^{1}$ It is arguably the case that The Daily Mail has moved away from its broadsheet format into more of a tabloid over the last decade or so. Despite this, the newspaper's 'middle-market' orientation provides it a unique position: residing somewhere between the broadsheet and tabloid markets.

${ }^{1}$ Most of the articles uncovered at the first stage were basic match reports that offered little beyond scores and performance reports, so these were not shortlisted unless they included data pertinent to the construction of Rusedski's identity or personal appearance.

\section{Conflict of Interest}

On behalf of all authors, the corresponding author states that there is no conflict of interest.

\section{References}


Aoki, D. (1996) Sex and muscle: The female bodybuilder meets Lacan. Body \& Society 2(4): 59-74.

Atkin, R. (1998) Hero of middle England. The Independent, 28 June.

Anthony, A. (1997) Wimbledon 97 preview. The Observer, 22 June.

Aughey, A. (2010) Anxiety and injustice: The anatomy of contemporary English nationalism. Nations and Nationalism 16(3): 506-24.

Baker, A. (1997) In the court of Lord Rusedski. The Daily Telegraph, 18 December.

Barnes, S. (1995) New arrival quickly starts to feel at home. The Times, 27 June.

Barnes, S. (1996) Congratulations Greg, you are now a true Brit. The Times, 28 June.

Barnes, S. (2004) Farewell to Quasi-Brit who never quite got it right. The Times, 9 January.

Barnes, S. (2007) Poor old Greg. So very nearly brilliant, so very nearly British. The Times, 9 April.

Barrett, J. (2004) Rusedski stays positive as storm rages. The Financial Times, 12 January.

Baucom, I. (1999) Out of Place. Princeton, NJ: Princeton University Press.

Bentley, N. (2007) Re-writing Englishness: imagining the nation in Julian Barnes's England, England and Zadie Smith's White Teeth. Textual Practice 21(3): 483-504.

Bignell, J. (1997) Media Semiotics: An Introduction. Manchester, UK: Manchester University Press.

Black, D. (2011) What Is a face? Body \& Society 17(4): 1-25.

Broadbent, R. (2003) England's dynamic duo. The Times, 23 June.

Cooke, R. (2001) I have just one friend in tennis... and it's not Tim Henman. The Sunday Telegraph, 17 June.

Dickson, M. (1997a) Put your money on Greg. Daily Mail, 25 June. 
Dickson, M. (1997b) Bitter taste for Rusedski. Daily Mail, 4 July.

Dickson, M. (1997c) Rusedski loses his cool as he falls under spell of the bogeyman. Daily Mail, 13 October.

Dolar, M. (1991) 'I shall be with you on your wedding-night': Lacan and the uncanny. October 58: 5-23.

Easthope, A. (1999) Englishness and National Culture. London, UK: Routledge.

Edensor, T. (2002) National Identity, Popular Culture and Everyday Life. Oxford, UK: Berg.

Edmondson, R. (2005) Tennis: Wimbledon 2005. The Independent, 21 June.

Edmunds, J. and Turner, B. (2001) The re-invention of national identity. Ethnicities 1(1): 83-108.

Edworthy, S. (1999) Nation poised for Brit awards. The Telegraph, 21 June.

Evans, A.B., Agergaard, S., Campbell, P.I., Hylton, K. and Lenneis, V. (2020) 'Black Lives Matter': Sport, race and ethnicity in challenging times. European Journal for Sport and Society. DOI: 10.1080/16138171.2020.1833499.

Fink, B. (2000) A Clinical Introduction to Lacanian Psychoanalysis. Cambridge, Mass: Harvard University Press.

Finlayson, A. (1998) Psychology, psychoanalysis and theories of nationalism. Nations and Nationalism 4(2): 145-62.

Gherovici, P. and Steinkoler, M. (2016) Introduction. In: P. Gherovici and M. Steinkoler (eds) Lacan, Psychoanalysis and Comedy. New York, NY: Cambridge University Press, pp.1-22.

Gilroy, P. (1998). Race ends here. Ethnic and Racial Studies 21(5): 838-47.

Gilroy, P. (2004) After Empire. Abingdon, UK: Routledge. 
Harris, J. (2019) Andy Murray and the borders of national identities: (Re)claiming a tennis champion. In: R.J. Lake (ed.) Routledge Handbook of Tennis: History, Culture and Politics. London, UK: Routledge.

Hayward, P. (1997) Gentleman Greg. The Guardian, 10 September.

Holden, J. (2001) Just a year ago he was being written off... . Sunday Express, 24 June. Howie, L. (2012) Witnesses to Terror. Basingstoke, UK: Palgrave Macmillan.

Inahara, M. (2009) This body which is not one: The body, femininity and disability. Body \& Society 15(1): 47-62.

Jones, S. (1995) Rusedski and Henman end four years of cup failure. The Times, 17 July.

Kumar, K. (2006) The Making of English Identity. Cambridge, UK: Cambridge University Press.

Lacan, J. (2000) The Psychoses: The Seminar of Jacques Lacan, Book III 1955-1956. Edited by J.-A. Miller. Translated by R. Grigg. London, UK: Routledge.

Lacan, J. (2010) Ecrits: A Selection. Translated by A. Sheridan. London, UK: Routledge.

Lacan, J. (2016) Anxiety: The Seminar of Jacques Lacan, Book X. Edited by J.-A. Miller. Cambridge, UK: Polity.

Lawton, J. (2002) Our players lack the killer instinct to be world class. The Independent, 22 January.

Lawton, J. (2003) Tennis: Wimbledon 2003. The Independent, 27 June.

Leonardo, Z. (2009) Race, Whiteness, and Education. New York: Routledge.

Lemma, A. (2017) The Digital Age on the Couch. London, UK: Routledge.

Levinas, E. (1998) Entre Nous: On Thinking-of-the-Other. Translated by M. Smith and B. Harshav. New York, NY: Columbia University Press. 
Long, J. and Hylton, K. (2002) Shades of white: An examination of whiteness in sport. Leisure Studies 21(2): 87-103.

Magli, P. (1989) The face and the aoul. In: M. Feher, R. Naddaff and N. Tazi (eds) Fragments for a History of the Human Body. New York, NY: Zone. Please insert page range.

Malcolm, D. (2012) Figuring Freddie: Andrew Flintoff, the Ashes and English national identity. Sport in Society 15(8): 1070-85.

Malcolm, D. (2013) Globalizing Cricket. London, UK: Bloomsbury.

McDonald, M.G. (2009) Dialogues on whiteness, leisure and (anti)racism. Journal of Leisure Research 41(1): 5-21.

McIntosh, P. (1988) White Privilege and Male Privilege: A Personal Account of Coming to See Correspondences through Work in Women's Studies. Wellesley, MA: Wellesley College Centre for Research on Women.

McMillan, C. (2015) Pedagogy of the impossible:Žižek in the classroom. Educational Theory 65(5): 545--62.

Myers, T. (2003) Salvoj Žižek. London, UK: Routledge.

Nasio, J-D. (1998) Five Lessons on the Psychoanalytic Theory of Jaques Lacan.

Albany, NY: State University of New York Press.

O’Hagan, S. (1995) Return of the instant hero. The Independent, 7 October.

O'Sullivan, J. (1998) What is Middle England? 29 September. https://www.independent.co.uk/news/what-is-middle-england-1201255.html, accessed 12 November 2019.

Philip, R. (1998) Unfriendly rivalry. The Daily Telegraph, 28 February.

Powell, J. (1997) Rusedski turns on power to reach last eight. Daily Mail, 2 September. 
Powell, J. (2004) We should have never given Greg any house room. Daily Mail, 9 January.

Riley, C. (1998) Sportsmen from across the board spend a week in the land of makebelieve. The Independent, 24 January.

Roberts, J. (1995) Centre court hails rampant Rusedski. The Independent, 29 June.

Roberts, J. (2001) Tennis. The Independent, 1 September.

Roberts, J. (2004) Rusedski drug scandal. The Independent, 9 January.

Ruti, M. (2015) The posthumanist quest for the universal: Butler, Badiou, Zižek. Angelaki 20(4): 193-210.

Seshadri-Crooks, K. (2000) Desiring Whiteness: A Lacanian Analysis of Race. London, UK: Routledge.

Skey, M. (2013) What does it mean to be cosmopolitan? An examination of the varying meaningfulness and commensurability of everyday 'cosmopolitan' practices. Identities 20(3): $235--52$.

Stafford, I. (1995) Rusedski enjoys a bumpy ride. The Independent, 31 October.

Taylor, C. (2012) Interculturalism or multiculturalism? Philosophy \& Social Criticism 38(4-5): 413-23.

The Independent (1995) Rusedski’s patriot games, 2 July. No journalist author?

Winnubst, S. (2004) Is the Mirror Racist?: Interrogating the Space of Whiteness. Philosophy \& Social Criticism 30(1): 25-50.

Wood, K. (2012) Žižek. Chichester, UK: Wiley-Blackwell.

Zalloua, Z. (2020) Žižek on Race. London, UK: Bloomsbury.

Žižek, S. (1996) Sex in the age of virtual reality. Science as Culture 5(4): 506-25.

Žižek, S. (2002) For They Know Not What They Do. London, UK: Verso.

Žižek, S. (2008) The Sublime Object of Ideology. London, UK: Verso. 
Žižek, S. (2016) Disparities. London, UK: Bloomsbury.

Zupančič, A. (2008) The Odd One In. Cambridge, Mass: The MIT Press.

Zupančič, A. (2019) Love thy Neighbor as thyself?! Problemi International 3(3): 89 108. 